\title{
Coincidence point theorems for cyclic multi-valued and hybrid contractive mappings
}

\author{
WARUt SAKSIRIKUN ${ }^{1}$, VASILE BERINDE ${ }^{2,3}$ and NARIN PETROT ${ }^{1,4}$
}

\section{ABSTRACT.}

In this paper, we consider the existence theorem of coincidence point for a pair of single-valued and multivalued mapping that are concerned with the concepts of cyclic contraction type mapping. Some illustrative examples and remarks are also discussed.

Acknowledgment. W. Saksirikun is supported by the Thailand Research Fund through the Royal Golden Jubilee PhD Program (Grant No. PHD/0248/2553)."

\section{REFERENCES}

[1] Abu-Donia, H. M., Common fixed points theorems for fuzzy mappings in metric space under $\varphi$-contraction condition, Chaos, Solitons \& Fractals, 34 (2007), 538-543

[2] Ahmad, A. and Imdad, M., Some common fixed point theorems for mappings and multi-valued mappings, J. Math. Anal. Appl., 218 (1998), No. 2, 546-560.

[3] Alghamdi, M. A., Berinde, V. and Shahzad, N., Fixed points of multivalued nonself almost contractions, J. Appl. Math. 2013, Art. ID 621614, 6 pp.

[4] Banach, S., Sur les opérations dans les ensembles abstraits et leur application aux équations intégrales, Fund. Math., 3 (1922), 133-181

[5] Berinde, V., Some remarks on a fixed point theorem for Ćirić-type almost contractions, Carpathian J. Math., 25 (2009), No. 2, 157-162

[6] Berinde, V., Approximating fixed points of implicit almost contractions, Hacet. J. Math. Stat., 41 (2012), No. 1, 93-102

[7] Berinde, M. and Berinde, V., On a general class of multi-valued weakly Picard mappings, J. Math. Anal. Appl., 326 (2007), No. 2, 772-782

[8] Berinde, V. and Păcurar, M., Coupled fixed point theorems for generalized symmetric Meir-Keeler contractions in ordered metric spaces, Fixed Point Theory Appl., 2012, 2012:115, 11 pp.

[9] Berinde, V. and Păcurar, M., Fixed point theorems for nonself single-valued almost contractions, Fixed Point Theory, 14 (2013), No. 2, 301-311

[10] Berinde, V. and Petric, M. A., Fixed point theorems for cyclic non-self single-valued almost contractions, Carpathian J. Math., 31 (2015), No. 3, 289-296

[11] Borcut, M., Tripled coincidence theorems for monotone mappings in partially ordered metric spaces, Creat. Math. Inform., 21 (2012), No. 2, 135-142

[12] Ćirić, L. B., Generalized contractions and fixed-point theorems, Publ. Inst. Math. (Beograd) (N.S.), 12(26) (1971), 19-26

[13] Ćirić, L. B., Fixed points for generalized multi-valued contraction, Matematicki Vesnik, 9(24) (1972), 265-272

[14] Damjanović, B. and Dorić, D., Multivalued generalizations of the Kannan fixed point theorem, Filomat, 25 (2011), No. 1, 125-131

Received: 25.11.2018; In revised form: 23.12.2018; Accepted: 30.12.2018

2010 Mathematics Subject Classification. 54H25, 54C60.

Key words and phrases. Coincidence point, common fixed point, multi-valued mapping, cyclic operator, Suzuki type contraction, Pompeiu-Hausdorff distance.

Corresponding author: Narin Petrot; narinp@nu.ac.th 
[15] Dhompongsa, S. and Yingtaweesittikul, H., Fixed points for multivalued mappings and the metric completeness, Fixed Point Theory Appl., 2009, Art. ID 972395, 15 pp.

[16] Dorić, D. and Lazović, R., Some Suzuki-type fixed point theorems for generalized multivalued mappings and applications, Fixed Point Theory Appl., 2011, 2011:40, 8 pp.

[17] Kamran, T., Coincidence and fixed points for hybrid strict contractions, J. Math. Anal. Appl., 299 (2004), No. $1,235-241$

[18] Kannan, R., Some results on fixed points, Bull. Calcutta Math. Soc., 10 (1968), 71-76

[19] Kaneko, H. and Sessa, S., Fixed point theorems for compatible multi-valued and single-valued mappings, Internat. J. Math. Math. Sci., 12 (1989), No. 2, 257-262

[20] Karapinar, E., Fixed point theory for cyclic weak $\phi$-contraction, Appl. Math. Lett., 24 (2011), No. 6, 822-825

[21] Karapinar, E. and Nashine, H. K., Fixed point theorem for cyclic Chatterjea type contractions, J. Appl. Math., 2012, Art. ID 165698, 15 pp.

[22] Karapinar, E. and Sadaranagni, K., Fixed point theory for cyclic $\phi$ - $\psi$-contraction, Fixed Point Theory Appl., 2011, 2011:69, 8 pp.

[23] Khan, A. A. and Sama, M., Optimal control of multivalued quasi variational inequalities, Nonlinear Anal., 75 (2012), No. 3, 1419-1428.

[24] Khan, A. R., Abbas, M. and Ali, B., Tripled coincidence and common fixed point theorems for hybrid pair of mappings, Creat. Math. Inform., 22 (2013), No. 1, 53-64

[25] Kirk, W. A., Srinivasan, P. S., and Veeramani, P., Fixed points for mappings satisfying cyclical contractive conditions, Fixed Point Theory, 4 (2003), No. 1, 79-89

[26] Kikkawa, M. and Suzuki, T., Three fixed point theorems for generalized contractions with constants in complete metric spaces, Nonlinear Anal., 69 (2008), No. 9, 2942-2949

[27] Kikkawa, M. and Suzuki, T., Some similarity between contractions and Kannan mappings, Fixed Point Theory Appl., 2008, Art. ID 649749, 8 pp.

[28] Kilbas, A. A., Srivastava H. M. and Trujillo, J. J., Theory and Applications of Fractional Differential Equations, North-Holland Mathematics Studies, 204, Elsevier Science B. V., Amsterdam, 2006

[29] Moţ, G. and Petruşel, A., Fixed point theory for a new type of contractive multivalued operators, Nonlinear Anal., 70 (2009), No. 9, 3371-3377

[30] Nadler Jr., S. B., Multivalued contraction mappings, Pacific J. Math., 30 (1969), 475-488

[31] Nashine, H. K., Cyclic generalized $\psi$-weakly contractive mappings and fixed point results with applications to integral equations, Nonlinear Anal., 75 (2012), 6160-6169

[32] Nashine, H. K., Sintunavarat, W. and Kumam, P., Cyclic generalized contractions and fixed point results with applications to an integral equation, Fixed Point Theory Appl., 2012, 2012:217, 13 pp.

[33] Padcharoen, A., Kumam, P. and Gopal, D., Coincidence and periodic point results in a modular metric space endowed with a graph and applications, Creat. Math. Inform., 26 (2017), No. 1, 95-104

[34] Păcurar, M. and Rus, I. A., Fixed point theory for cyclic $\varphi$-contractions, Nonlinear Analysis, 72 (2010), $1181-1187$

[35] Petric, M. A., Some results concerning cyclical contractive mappings, General Math., 18 (2010), No. 4, 213-226

[36] Petruşel, A. and Petruşel, G., A note on multivalued Meir-Keeler type operators, Stud. Univ. Babeş-Bolyai Math., 51 (2006), No. 4, 181-188

[37] Popa, V., Two coincidence and fixed point theorems for hybrid strict contractions, Math. Morav., 11 (2007), 79-83

[38] Radenović, S., A note on fixed point theory for cyclic weaker Meir-Keeler function in complete metric spaces, Int. J. Anal. Appl., 7 (2015), No. 1, 16-21

[39] Raines, B. E. and Stockman, D. R., Fixed points imply chaos for a class of differential inclusions that arise in economic models, Trans. Amer. Math. Soc., 364 (2012), No. 5, 2479-2492

[40] Rus, I. A., Cyclic representations and fixed points, Ann. Tiberiu Popoviciu Semin. Funct. Equ. Approx. Convexity, 3 (2005), 171-178

[41] Sabatier, J., Agrawal, O. P. and Machado, J. A. T., Advances in Fractional Calculus: Theoretical Developments and Applications in Physics and Engineering, Springer, Dordrecht, 2007

[42] Singh, S. L. and Mishra, S. N., Coincidences and fixed points of nonself hybrid contractions, J. Math. Anal. Appl., 256 (2001), No. 2, 486-497

[43] Sintunavarat, W. and Kumam, P., Common fixed point theorem for cyclic generalized multi-valued contraction mappings, Appl. Math. Lett., 25 (2012), No. 11, 1849-1855 
1 Department of MATHEMatics

FACULTY OF SCIENCE

NARESUAN UNIVERSITY

PHITSANULOK 65000, THAILAND

Email address: w_saksirikun@hotmail.co.th

2 Department of MATHEMATICS ANd COMPuter SCIENCE

North University Center at Baia Mare

TECHNICAL UNIVERSITY OF CLUJ-NAPOCA

ViCTORIEI 76, 430122 BAIA MARE, ROMANIA

3 ACADEMY OF ROMANIAN SCIENTISTS

Email address: vberinde@cunbm.utcluj.ro

1,4 Centre of ExCEllence in Nonlinear Analysis and Optimization Faculty of Science NARESUAN UNIVERsity PHITSANULOK, THAILAND

Email address: narinp@nu.ac.th 